\title{
Modulation of programmed cell death by honey bee in human prostate adenocarcinoma
}

\author{
Saeed Samarghandian ${ }^{1 \star}$, Jalil Tavakkol Afshari ${ }^{2 \star}$ and Saeideh Davoodi ${ }^{1}$ \\ ${ }^{1}$ Department of Physiology, Faculty of Medicine, Mashhad University of Medical Sciences, Mashhad, Iran. \\ ${ }^{2}$ Imunology Research Center, BuAli Research Institute, Mashhad Univ ersity of Medical Sciences, Mashhad, Iran.
}

Accepted 18 October

\begin{abstract}
The search for new anti-cancer drugs from natural products is one of the most prominent research areas of treatment of cancer. Honey finds a vital role in various applications using its anti-inflammatory, antioxidant, antibacterial and antitumor properties. We investigated the potential of honey to induce cytotoxic and antiproliferative effects in cultured human prostate cancer cell line (PC-3) in comparison to non-malignant (L929) cells. Both cells were cultured in RPMI medium and treated with the selected crude honey sample at various concentrations $(5,10$ and $15 \%)$ for three consecutive days. The results revealed that the cell viability decreased in a concentration and time- dependent manner in the malignant cells treated with honey in comparison with non-malignant cells. Honey showed antiproliferative activity with the $\mathrm{IC}_{50}$ value 4,10 and $14 \%$ after 24,48 and $72 \mathrm{~h}$, respectively in PC-3 cell line. Overall, it can be concluded that higher concentrations of honey is safe for L929, but it exerts antitumor cytotoxicity and anti-proliferative effects in a prostate cancer-derived cell line. Thus, it is considered as a potential chemotherapeutic agent against prostate cancer.
\end{abstract}

Key words: Anti-proliferative, programmed cell death, Honey bee, human prostate adenocarcinoma, MTT.

\section{INTRODUCTION}

Prostate cancer is the most common diagnosed malignancy and the second leading cause of male death in Western countries (Crawford, 2003) and produces killing about 200,000 men annually throughout the world. Mortality from prostate cancer results from metastases to the bones and lymph nodes. Clinically, prostate cancer is usually diagnosed in men over 50 years of age; with increasing life expectancy, the incidence of prostate cancer is likely to increase worldwide (Peter et al., 1995).

Cancer therapy is generally classified into three categories: surgery, radiation therapy and chemotherapy. Chemotherapy is the administration of drugs that can regulate the uncontrolled proliferation of abnormal cancer cells. Tumor cells very often develop resistance to

\footnotetext{
*Corresponding author. E-mail: TavakolAJ@mums.ac.ir.
}

chemotherapy. On the other hands, approximately $75 \%$ of patients have surgically incurable disease at the time of diagnosis. There are few drugs which achieve a complete recovery in cancer patients and the failure of conventional chemotherapy to induce a major reduction in mortality indicates that the development of more effective chemotherapeutic drugs is essential for treatment of cancer worldwide. Thus, there is a promising opportunity for its intervention using cancer chempopreventive compounds that can prevent or slow the progression cancer disease (Tsao et al., 2004), (Jain et al., 1999).

Several epidemiological studies have shown a strong correlation between consumption of diets rich in natural products and vegetables and a lower risk of various cancers (Norman and Kerri, 2003). For a variety of reasons naturally occurring botanicals and natural dietary sub-stances are gaining increasing attention as cancer chemopreventive agents. Important for prostate cancer chemproprevention is the fact that in recent years, the 
use of natural dietary substances and botanical products is showing sustained increase by prostate cancer patients. In prostate cancer a fine balance between cell proliferation and apoptotic death is lost which contributes to increase cellular mass and tumor progression. In this regard, for prostate cancer chemoprevention at the present time there is considerable emphasis in identifying novel natural products that selectively induces apoptosis and growth arrest of prostate cancer cells without our less producing cytotoxic effects on normal cells.

Honey bee finds a role in both domestic and medicinal applications. It has been widely used as sweetener since ancient times. Composition of honey varies depending upon the geographical and the nectar sources of a region. The quality of the honey bee depends upon its physiochemical and sensory properties. Hence knowledge about its constituents is essential in judging its quality (Al-Khalifa and Al-Arify, 1999).

Recent studies revealed that phenolic compounds present in the honey can act as potent antioxidants in comparison with other constituents like Vitamins $\mathrm{C}$ and $\mathrm{E}$ (Nagendran et al., 2006; Elisabete et al., 1998). Consumption of certain dietary components has been related to several protective effects against cancer and also several other disorders such as diabetes and rheumatoid disease (Wollgast and Anklam, 2000). Honey is thought to exhibit a broad spectrum of therapeutic properties including antibacterial, antifungal, cytostatic and antiinflammatory activity (Burdock, 1998; ljaz et al., 2008). Honey has been used for the treatment of abdominal wound disruption, gastric ulcers, gastroenteritis and burns and for the storage of skin grafts (Lutfi et al., 2006).

Recent studies by Gribel and Pashiniski indicated that honey possessed moderate antitumor and pronounced antimetastatic effects in five different strains of rat and mouse tumors (Gribel and Pashiniski, 1990). Furthermore, honey potentiated the antitumor activity of chemotherapeutic drugs such as 5-fluorouracil and cyclo-phosphamide (Wattenberg, 1986). Honey contained many biologically active compounds including caffeic acid (Mohamed and Mona, 2010), caffeic acid phenethyl ester (Mohamed and Mona, 2010) and flavonoid glycones (Yen et al., 2003). These compounds demonstrated to have an inhibitory effect on tumor cell proliferation and transformation by the down regulation of many cellular enzymatic pathways including protein tyrosine kinase, cyclooxygenase and ornithine decarboxylase pathways (Jim et al., 2003). Since honey is one of the common foods for humans, it prompted us to investigate it as a potential candidate for cancer treatment.

\section{MATERIALS AND METHODS}

\section{Materials}

3-(4, 5-Dimethylthiazol-2-yl)-2, 5-diphenyl (MTT) was purchased from Bioseen Technology, Inc. RPMI 1640 was purchased from Igbo BRL (Grand Island, NY, USA). Fetal bovine serum was purchased from PAA Laboratories $\mathrm{GmbH}$, Austria.

\section{Honey}

Pure unfractionated honey bee was purchased from AliBaba (India) and diluted with RPMI-1640 medium to prepare concentrations of 0 to $15 \%(0,5,10$, and $15 \%)$ to be used in the in vitro studies.

\section{Cell lines}

Two different cell lines were used in this study. The human prostate cancer cell lines designated as PC-3 and mouse fibroblast cell line designated as L929 were obtained from the Pasture Institute in Tehran, Iran.

\section{Cell culture}

Human prostate cancer cell line (PC-3) was maintained as monolayer cultures in RPMI-1640 supplemented with $10 \%$ fetal calf serum, $1 \%$ glutamine and $1 \%$ each penicillin and streptomycin. The cells were cultured in a 96-well tissue culture plates for $24 \mathrm{~h}$. The culture medium was then aspirated and a 5, 10 and $15 \%$ dilution of honey in RPMI-1640 was added. The plates were maintained at $37^{\circ} \mathrm{C}$ in $5 \% \mathrm{CO}_{2}$ in humidified air for $72 \mathrm{~h}$ and then examined by phase contrast microscopy.

\section{MTT assay}

After $72 \mathrm{~h}$ incubation of PC-3 cells in various dilutions of honey ( 0 to $15 \%$ ) in 96- well tissue culture plates, $10 \mathrm{~m} \mathrm{~L}$ of MTT reagent (1 $\mathrm{mg} / \mathrm{mL}$ ) was added to each well, and the plates were incubated for 3 to $4 \mathrm{~h}$. The medium was then aspirated, and $100 \mu \mathrm{L}$ DMSO $(100 \%)$ was added. The highly colored DMSO-soluble Formazan product was assessed spectrophotometrically by employing a microplate reader.

\section{Morphological studies}

Morphological studies by using normal inverted microscope were carried out to observe the morphological changes of cell death in malignant (PC-3) and nonmalignant cell (L929) lines elicited by different concentration of honey. Concentration of (5, 10 and 15\%) of honey was used for the morphological studies. The untreated cells served as the negative control. The morphological alterations of the cells were visualized under the normal inverted microscope after 24,48 and $72 \mathrm{~h}$ post-treatment.

\section{Determination of IC50}

Plots of percent cytotoxicity index $(\% \mathrm{Cl}=[1-\quad(\mathrm{OD} 570-630$ treated/OD570-630 control)] $\times 100$ ) versus concentrations were drawn from the experiments. $\mathrm{IC}_{50}$, honey concentration resulting in $50 \%$ cytotoxicity was determined from the graph.

\section{Statistical analysis}

Significant level was ascertained by one way analysis of variance, followed by Tukey multiple comparison tests. Results were expressed as the mean \pm SEM. A $p$ value of $<0.05$ in Tukey test was considered significant. Statistical procedures were performed with SPSS software. 


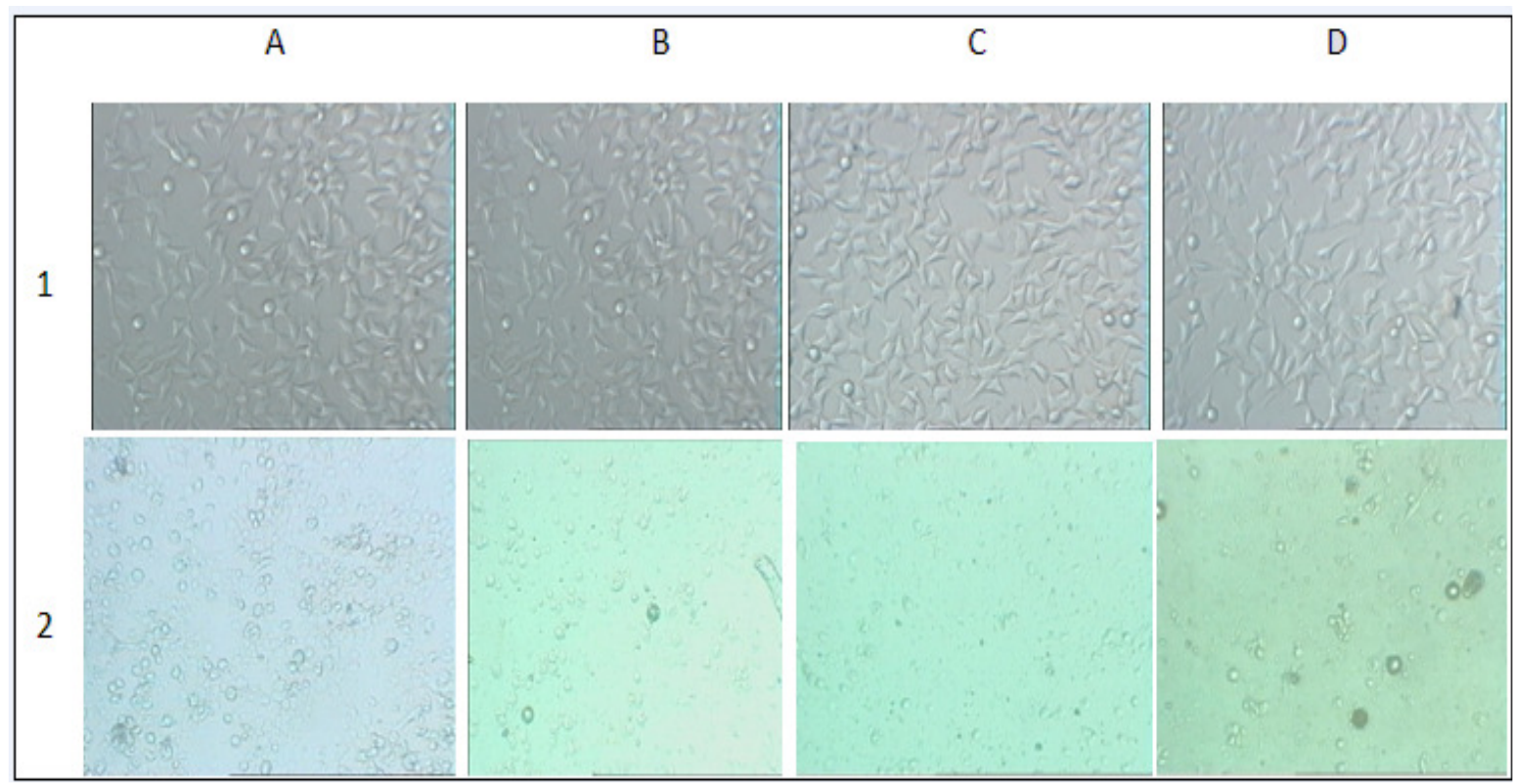

Figure 2. Comparison cytotoxicty effect of honey on cell viability of prostate cancer cell (PC-3) and non-malignant cell (L929) line after $24 \mathrm{~h}$. Morphological changes of cells after treatment with different concentration of honey. 1: L929 cell line; 2: PC-3 cell line; $A=0 \% ; B=5 \% ; C=10 \%$ and $D=15 \%$ honey.

\section{RESULTS}

To discriminate between early and late effects of honey action, malignant (PC-3) and non-malignant control (L929) cells were exposed to increasing concentrations of honey for 24,48 and $72 \mathrm{~h}$.

\section{Morphological evaluation of the effect of honey on cell viability}

After $24 \mathrm{~h}$ co-culture of the cells with different concentration of honey $(5,10$ and $15 \%)$, cell population was decreased as compared to control and also morphologic changes were observed in the prostate cancer cells versus L929 cells which is consisting of eduction in number of living cells, volume and rounding until the nucleus constituted the majority of the cellular volume. The reduction of malignant cells (PC-3) compared to L929 was statistically highly significant. This cytotoxicity was increased at higher concentrations (Figure 2). After $48 \mathrm{~h}$ of incubation with honey moderate cytoplasmic granulations were apparent and a large number of cells became rounded at each dose. On day 3 , nearly $90 \%$ of surface in the control flasks were confluent, while in all honey concentrations about $20-10 \%$ of surface covered by PC-3 cells. So that, honey treated prostate cancer cells (5, 10 and $15 \%)$ were damaged but there were no morphological changes in honey treatedL929 cells at the same concentrations (Figure 3). After 24, 48 and 72 h, there was no clear morphological changes were detected in L929 cells at any dose of honey (Figures 2 and 3).

\section{Effect of honey on cell viability}

In order to evaluate the effect of honey on growth of prostate cancer cells and L929, the cells were incubated with different concentrations of honey $(5,10$ and $15 \%)$ for 24, 48 and $72 \mathrm{~h}$ and their growth inhibitory effects were compared. MTT assay, a simple and reliable technique, which measures cell viability, can be used for screening of anti-proliferative agents. The assay was repeated five times; there was a concentration-dependant antitumor effect in prostate cancer cell line. Honey showed significantly high growth inhibitory effects on prostate cancer cell line in a concentration and time- dependent manner compared to the L929. As shown in Figure 1 honey $(5,10$ and $15 \%$ ) decreased cell viability in malignant cells (PC3) but not in non-malignant cells (L929) after $24 \mathrm{~h}$. This toxicity was consistent with morphologic changes. However, honey at different concentrations could not significantly decrease cell viability in L929 cells. Table 1 presented the dose inducing $50 \%$ cell growth inhibition $\left(\mathrm{IC}_{50}\right)$. The $\mathrm{IC}_{50}$ values determined from different honey concentration on PC-3 cell lines. Honey ( 72 h) showed potent cytotoxic effects with the $\mathrm{IC}_{50}$ values of $4 \%$ in PC3 line or 2.5 times more potent than $48 \mathrm{~h}$ exposure(10\%) whereas honey $(24 \mathrm{~h})$ gave the $\mathrm{IC}_{50}$ values of $14 \%$ in PC-3 cell line, which was about 3.5 times less potent than $24 \mathrm{~h}$ exposure.

\section{DISCUSSION}

The therapeutic activity of most anticancer drugs in 


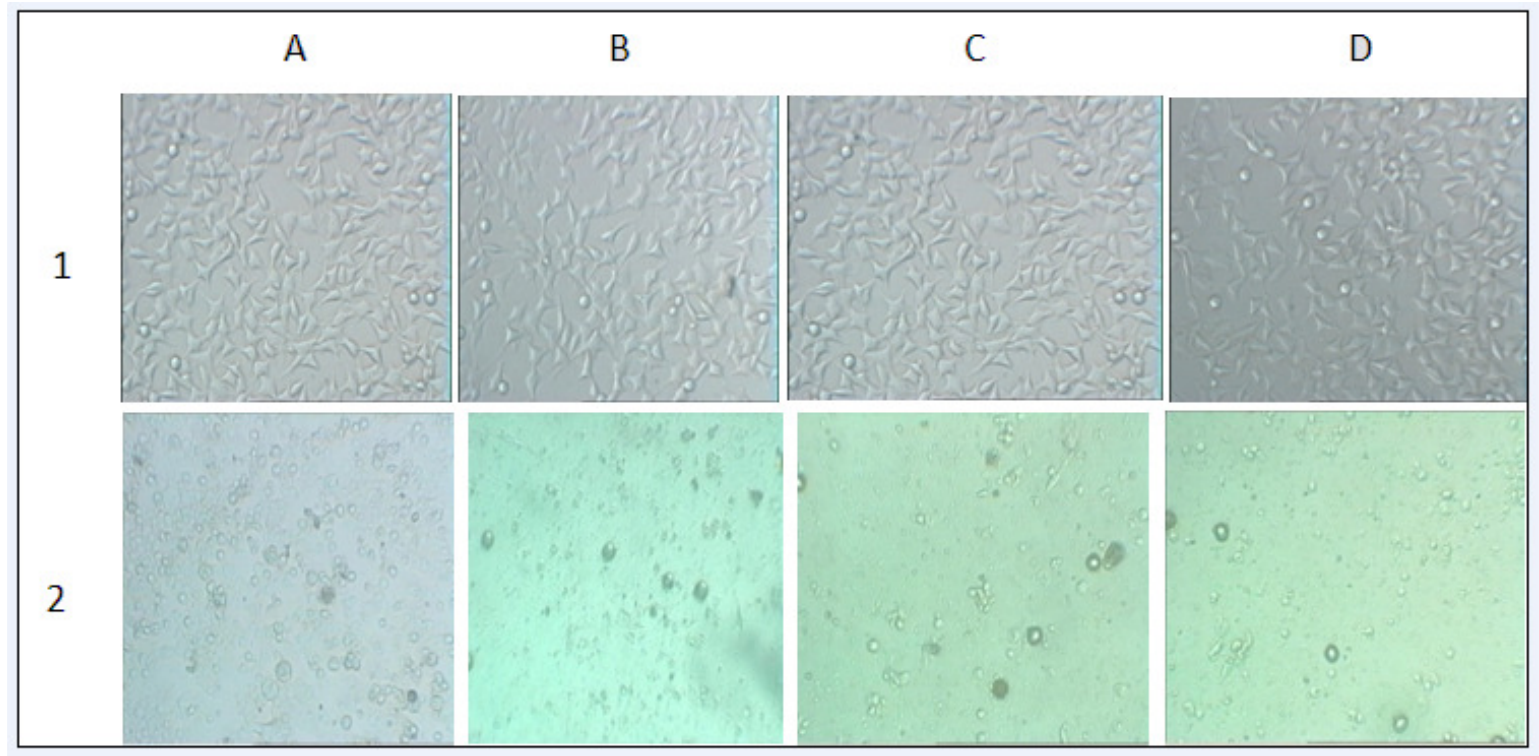

Figure 3. Comparison cytotoxicty effect of honey on cell viability of prostate cancer cell (PC-3) and non-malignant cell (L929) line after $48 \mathrm{~h}$. Morphological changes of cells after treatment with different concentration of honey. 1 : L929 cell line; 2: PC-3 cell line; $A=0 \% ; B=5 \% ; C=10 \%$ and $D=15 \%$ honey.

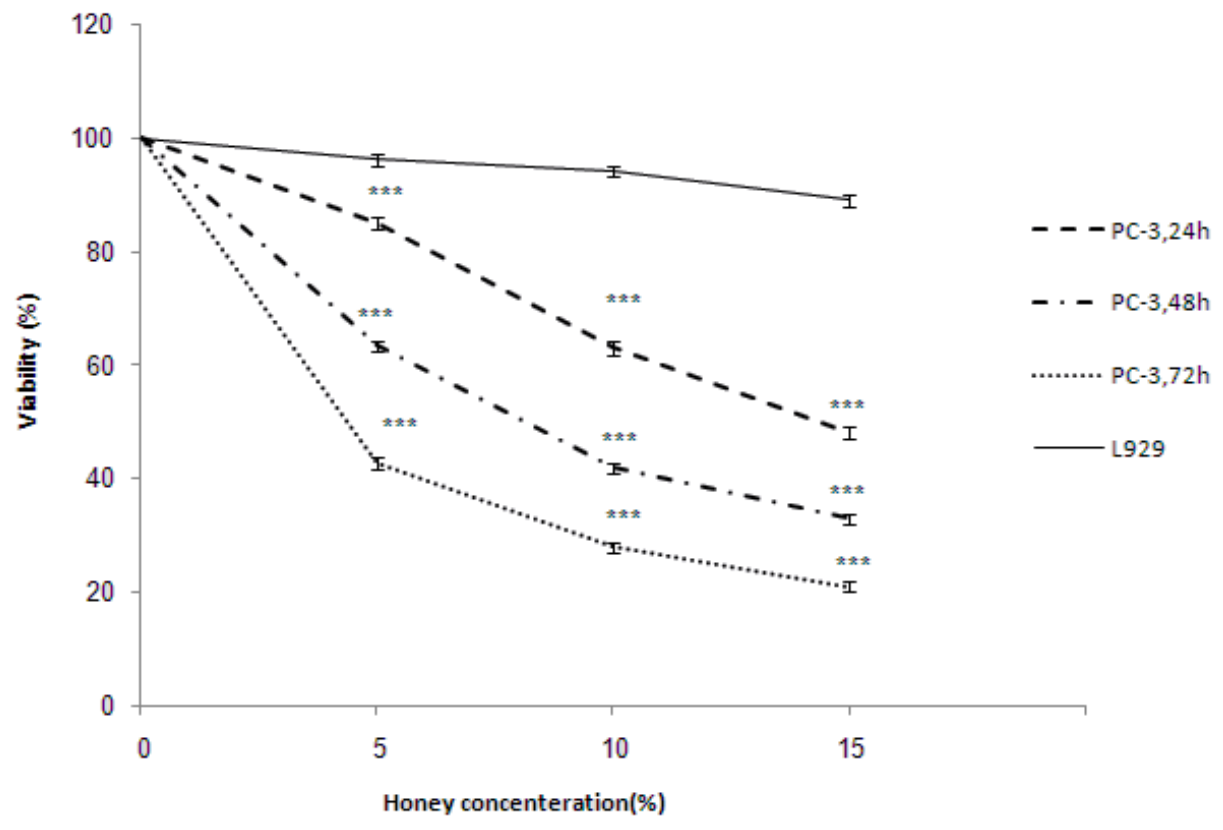

Figure 1. Effect of honey on cell viability of PC-3 cells. Cells were treated with different concentration of honey for 24,48 and $72 \mathrm{~h}$. Viability was quantitated by MTT assay. Results are mean \pm SEM. The asterisks are indicator of statistically difference obtained separately at different time points compared to their controls shown in figure as ${ }^{* * *} p<0.001$.

clinical use is limited by their general toxicity toproliferating cells, including some normal cells. Although, chemists continue to develop novel cytotoxic agents with unique mechanisms of action, many of these compounds still lack tumor selectivity and have not been therapeutically useful (Rao et al., 2005; Chari, 2008). New targets for cancer therapy focus on interfering with specific targeted molecules needed for carcinogenesis and tumor growth in order to overcome the problems of traditional therapies (Goldman, 2003). Natural products are perceived as pure, and without side effects medication products (Montbriand, 2004). Many patients with cancer or other chronic conditions use alternative therapies, often herbal or natural products (Montbriand 
Table 1. Doses inducing $50 \%$ cell growth inhibition $\left(\mathrm{IC}_{50}\right)$ of Honey extract against prostate cancer cell line (PC-3).

\begin{tabular}{lccc}
\hline $\mathbf{I C}_{50}$ & $\mathbf{2 4} \mathbf{~ h}$ & $\mathbf{4 8} \mathbf{~ h}$ & $\mathbf{7 2 ~ h}$ \\
\hline $\mathrm{PC}-3$ & $14 \pm 1.0(\%)$ & $10 \pm 0.9(\%)$ & $4 \pm 0.05(\%)$ \\
\hline
\end{tabular}

Cells were treated with different concentration of Honey for 24 and $48 \mathrm{~h}$. Viability was quantitated by MTT assay.

$1995,2000,1994)$. Honey, which is one of the most complex mixtures of carbohydrates produced in nature (Roderick and Lise, 1999), has a long history as a medicinal substance. It is a known natural product with several biological activities. Some bioactive compounds have been found in honey such as chrysin which have been used to prevent cancer, in a similar fashion as anastrozole (a breast cancer drug), and treat conditions such as anxiety and inflammation (Galijatovic et al., 2000, 2001).

The objective of our in vitro study was to investigate the cytotoxicity and anti-proliferative activity of a range concentration of honey against human prostate cancer cell lines. Honey is also known as a dietary source for flavonoids (Marie et al., 1996) which have been demonstrated to have anti-carcinogenic and anti-inflammatory activities (Abdel et al., 2009). Although crude honey was reported by some authors as a proliferative agent that enhances the proliferation of both normal and malignant cells (Abuharfeil et al., 1999; Tonks et al., 2001), it was also reported as a promising antitumor agent with pronounced antimetastatic effect (Orsolić et al., 2005). The proliferative effect of honey on tumor cells was suggested to be a nutritional effect rather than a carcinogenic effect, and the antitumor effect was reported to result from many activities such as the inhibition of DNA synthesis with no signs of cytotoxicity (Saravana and Mahitosh, 2009).

In vitro study showed that diluted honey affected the growth patterns of prostate cancer cells. The effect was observed to be dependent on the duration and concentration of honey used. According to the results of MTT cytotoxicity test and morphological evaluation, all concentrations of honey exhibited antiproliferative effect on PC-3 cells with no significant differences on L929 cells. The cytotoxic effect of honey can be explained by the fact that honey is a dietary source of phenolic compounds that are referred to as flavonoids. These compounds have been isolated from several types of honey and they have been reported as potent anticancer agents that can be extracted from their sources mainly by ethyl acetate (Yang et al., 2008). Cafeic acid (3,4-dihydroxycinnamic acid) ester derivates, which are present in honey at levels of 10 to $20 \%$ (total phenolic compounds), are thought to exhibit a broad spectrum of activities that possibly include tumor inhibition (Wei et al., 2007). Several cellular components that have been associated with cell proliferation, such as polyamines and polyamine synthetic enzyme activities including ornithine decarboxylase, are presents at high levels in proliferating normal and neoplastic cells (Karima et al., 1999; Susan, 2007). In addition many kinases, such as tyrosine protein kinase (TPK), mediate proliferative as well as metabolic signals in the cells (Lise and Richard, 1994). Eicosanoids, the metabolites of arachidonic acid through the lipoxygenase and cyclooxygenase pathways, exerts a variety of biological activities (Marta et al., 2005). The cytotoxic effect of chloroform extract of $\mathrm{H} 1$ may be attributed to the fact that honey may contain pyrrolizidine alkaloids which considered as toxic compounds that were extracted by chloroform (Deinzer et al., 1977).

Chloroform/methanol solvent was reported to extract lipids, including unsaturated fatty acids. It was reported that unsaturated fatty acids possess a broad spectrum of biological properties in both animals and plants and some of these compounds show biological activity, e.g., 9,10dihydroxy-8-oxo-12Zoctadecaenoic acid exhibits cytotoxicity against HeLa cells and an inhibitory effect on tea pollen growth; it was also reported that the lipid fraction extracted from Agaricus blazei by chloroform/methanol retarded tumor growth (Takaku et al., 2001). Thus the cytotoxic effect of the chloroform/methanol extract of all tested honeys may be attributed to the presence of cytotoxic lipid contents of honeys and, probably, to other cytotoxic component(s). In our studies, treatment of cancer cell with honey resulted in a significant lowering of the profileration compared to control cells, supporting our hypothesis about the anti proliferative and cytotoxic effect of honey in prostate cancer.

In conclusion, honey can be considered as promising antitumor agents where they inhibited the proliferation. Further investigations are needed to study in details the composition and mechanism of action of honey on PC-3 and other cell lines.

\section{ACKNOWLEDGMENT}

The authors would like to thank Research Affairs of Mashhad University of Medical Sciences for financially supporting this work.

\section{REFERENCES}

Abdel AA, Rady HM, Amer MA, Kiwan HS (2009). Effect of some 
honey bee extracts on the proliferation, proteolytic and gelatinolytic activities of the hepatocellular carcinoma hepg2 cell line. Aust. J. Basic Appl Sci., 3: 2754-2769.

Abuharfeil N, AlOran R, Aboshehada M (1999). The effect of honey bee on the proliferative activity of human B and T-lymphocytes and the activity of phagocytes. Food Agric. Immunol., 11: 169-177.

Al-Khalifa AS, Al-Arify IA (1999). Physicochemical characteristics and pollen spectrum of some Saudi honeys. Food Chem., 67: 21-25.

Burdock GA (1998). Review of the biological properties and toxicity of bee propolis (propolis). Food Chem. Toxicol., 36: 347-363.

Chari RV (2008). Targeted cancer therapy: conferring specificity to cytotoxic drugs. Acc. Chem. Res. Rev., 41:98-107.

Crawford ED (2003). Epidemiology of prostate cancer. Urology, 62:312.

Deinzer ML, Thomson PA, Burgett DM, Isaacson DL (1977). Pyrrolizidine alkaloids: their occurrence in honey from tansy ragwort (Senecio jacobaea L.). Science, 195:497-499.

Elisabete G, Leonor M A, Teresa CPD (1998). Antioxidant activity of 5 aminosalicylic acid against lipid peroxidation in the presence of vitamins $C$ and E. Int. J. Pharm., 172:219-228.

Galijatovic A, Otake Y, Walle UK, Walle T (2001). Induction of UDPglucuronosyltransferase UGT1A1 by the flavonoid chrysin in Caco-2 cells--potential role in carcinogen bioinactivation. Pharm. Res., 18:374-349

Galijatovic A, Walle UK, Walle T (2000). Induction of UDP. glucuronosyltransferase by the flavonoids chrysin and quercetin in Caco-2 cells. Pharm. Res., 17:21-26.

Goldman B (2003). Combinations of targeted therapies take aim at multiple pathways. J. Natl. Cancer Inst., 22:1656-1657.

Gribel NV, Pashiniski VG (1990). Antitumor properties of honey. Vopr Onkol., 36:704-707.

ljaz T, Ranjha FA, Shahzad MKK, han MA, Imran M, ljaz N, ljaz S (2008). Antibacterial and Antifungal Activity of Different Honeys. Int. J. Infect. Dis., 12:e403.

Jain MG, Hislop GT, Howe GR, Ghadirian P (1999). Plant foods, antioxidants, and prostate cancer risk: findings from case-control studies in Canada. Nutr. Cancer, 34:173-184.

Jim OP, Judith B, Janis F, Paul RH (2003). Effects of dietary flavonoids on major signal transduction pathways in human epithelial cells. Bioch. Pharmacol., 66:2075-2088.

Karima M, Robert B, Sylvain M, Antoine M, Mohammed B, Jacques R, Daniel $T$ (1999). Effects of a high soy protein diet on intestinal polyamines and ornithine decarboxylase activity in rats. J. Nutr. Biochem., 10:405-410.

Lise T, Richard B (1994). Protein tyrosine phosphorylation in normal rat tissues. Int. J. Biochem., 26:29-34.

Lutfi T, Fikret E, Yusuf KI, Ahmet C, Orhan Y (2006). Fournier's gangrene: Report of thirty-three cases and a review of the literature. Int. J. Urol., 13:960 - 967.

Marie HS, Anne MLB, Marie CCL, Marie JA, Sylvie S, Serge YA, Marc S (1996). Flavonoids of Honey and Propolis: Characterization and Effects on Hepatic Drug-Metabolizing Enzymes and Benzo[a]pyrene-DNA Binding in Rats . J. Agric. Food Chem., 44:2297-2301.

Marta LP, Joan C, Esther T, Anna P, Marcelina P, Jaime LM, Wladimiro $J$, Vicente A, Francisca R, Joan R (2005). The selective cyclooxygenase-2 inhibitor celecoxib modulates the formation of vasoconstrictor eicosanoids and activates PPARy. Influence of albumin. J. Hepatol., 42:75-81.

Mohamed FE, Mona ME (In Press 2010). Inhibitory Effect of Caffeic Acid Phenethyl Ester on Mice Bearing Tumor Involving Angiostatic and Apoptotic Activities. Chemico-Biological Interactions.

Montbriand MJ (1995). Alternative therapies as control behaviours used by cancer patients. J. Adv. Nurs., 22:646-654.

Montbriand MJ (2000). Alternative therapies. Health professionals' attitudes. Can. Nur., 96:22-26.
Montbriand MJ (1994). An overview of alternate therapies chosen by patients with cancer. Oncol. Nurs. Forum, 21:1547-1554.

Montbriand MJ (2004). Herbs or natural products that protect against cancer growth part three of a four-part series. Oncol. Nurs. Forum Rev., 31:127-146.

Nagendran B, Kalyana S, Samir (2006). Phenolic compounds in plants and agri-industrial by-products: Antioxidant activity, occurrence, and potential uses. Food Chem., 99:191-203.

Norman JT, Kerri KG (2003). Fruit, vegetables, and the prevention of cancer: Research challenges. Nutrition 19:467-470.

Orsolić N, Terzić S, Mihaljević Z, Sver L, Basić I (2005). Effects of local administration of propolis and its polyphenolic compounds on tumor formation and growth. Biol. Pharm. Bull., 28:1928-1933.

Peter B, Patrick M, Pavel N (1995). Geographical and temporal patterns of incidence and mortality from prostate cancer. Urology 46:47-55

Rao JS, Gondi C, Chetty C, Chittivelu S, Joseph PA, Lakka SS (2005). Inhibition of invasion, angiogenesis, tumor growth, and metastasis by adenovirus-mediated transfer of antisense UPAR and MMP-9 in nonsmall cell lung cancer cells. Mol. Cancer Ther., 9:1399-1408.

Roderick JW, Lise KB (1999). The oligosaccharide composition of some New Zealand honeys. Food Chem., 64:33-37.

Saravana KJ, Mahitosh M (2009). Antiproliferative Effects of Honey and of Its Polyphenols: A Review. J. Biomed. Biotechnol., pp. 1-13.

Susan GK (2007). Polyamines and nonmelanoma skin cancer. Toxicol. Appl. Pharm., 224:249-256.

Takaku T, Kimura Y, Okuda H (2001). Isolation of an antitumor compound from Agaricus blazei Murill and its mechanism of action. J. Nutr., 131:1409-1413.

Tonks A, Cooper RA, Price AJ, Molan PC, Jones KP (2001). Stimulation of TNF-alpha release in monocytes by honey. Cytokine 14:240-242

Tsao AS, Kim ES, Hong WK (2004). Chemoprevention of cancer. J. Clin. CA. Cancer, 54:150-180.

Yang EC, Chuang YC, Chen YL, Chang LH (2008). Abnormal foraging behavior induced by sub-lethal dosage of imidacloprid in the honey bee (Hymenoptera: Apidae). Econ. Entomol., 101:1743-1748.

Yen CC, Shing CS, Hui YL (2003). Rutinoside at C7 attenuates the apoptosis-inducing activity of flavonoids. Bioch. Pharmaco., 66:11391150.

Wattenberg LW (1986). Chemoprevention of cancer by naturally occurring and synthetic compounds.In: Wattenberg LW, Lipkin M, Boone GJ, Kellof (eds).Cancer Chemoprevention CRC Press, Boca Ranton, pp. 19-40.

Wei MW, Liang L, Yuan L, Ting W, Lei L, Qiang C, Rui W (2007). Free radical scavenging and antioxidative activities of caffeic acid phenethyl ester (CAPE) and its related compounds in solution and membranes: A structure-activity insight. Food Chem., 105:107-115.

Wollgast J, Anklam E (2000). Review on polyphenols in theobroma cacao: changes in composition during the manufacture of chocolate and methodology for identification and quantification. Food Res. Int., 33:423-447. 